\title{
Hypogammaglobulinaemia associated with normal or increased IgM (the hyper IgM syndrome): a case series review
}

\author{
N Banatvala, J Davies, M Kanariou, S Strobel, R Levinsky, G Morgan
}

\begin{abstract}
The clinical and immunological aspects of 16 children with the syndrome of hypogammaglobulinaemia associated with normal or increased IgM (the hyper IgM syndrome) and their responses to treatment are reviewed. Increased concentrations of IgM, neutropenia, and recurrent infections could usually be controlled by antimicrobial and intravenous immunoglobulin treatment. Together with the bacterial infections characteristic of hypogammaglobulinaemia, these patients often developed opportunistic infections, including Pneumocystis carinii pneumonia, often presenting in the first year of life. The occurrence of sclerosing cholangitis, neurological complications, and neutropenia may be a result of an underlying cell mediated immune deficiency, autoimmunity, or infection. Despite a high incidence of opportunistic infections, immunological investigations did not show any abnormality of $T$ cell function. These findings are discussed in the light of the recent demonstration that the lack of expression of a $T$ lymphocyte activation antigen is the molecular basis of the $X$ linked form of the disorder.

(Arch Dis Child 1994; 71: 150-152)
\end{abstract}

Primary hypogammaglobulinaemia associated with normal or increased IgM ( the hyper IgM syndrome) was first described in 1961.1 A literature review from 1992 documents only 67 cases and describes considerable genetic heterogeneity within this group. ${ }^{2}$ Inheritance is usually $\mathrm{X}$ linked ${ }^{3}$ but in addition may be autosomal dominant ${ }^{4}$ and autosomal recessive. ${ }^{1}$ The gene for the $\mathrm{X}$ linked form has been cloned by several groups and encodes a $\mathrm{T}$ cell activation molecule which is the ligand for the CD40 molecule. ${ }^{56} \mathrm{X}$ linked hyper IgM is distinguished from the more common $\mathrm{X}$ linked agammaglobulinaemia (Bruton's disease) by the presence of circulating B lymphocytes and polyclonal IgM in X linked hyper IgM syndrome, which are absent in $\mathrm{X}$ linked agammaglobulinaemia. Like $\mathrm{X}$ linked agammaglobulinaemia, hyper IgM syndrome is regarded as a primary humoral defect, but there are prominent features that suggest a $T$ lymphocyte deficiency. We describe the clinical and laboratory features of 16 children with hyper IgM syndrome and discuss the pathogenetic mechanisms implied by these observations.

\section{Methods}

Sixteen children who presented to the Hospital for Sick Children, London and the 'Aghia Sophia' Children's Hospital between 1977 and 1991 with this syndrome are reviewed. Clinical, genetic, and immunological features and their response to treatment have been retrospectively studied. Four of these patients have been partially described previously: patients 1 and $2^{7}$ and patients 12 and 13.8

\section{Results}

FAMILY HISTORIES

Fourteen of the 16 patients were boys and a family history of immunodeficiency or unexplained death in childhood was suggested in seven (table 1). Of the 16 patients, two sets of children were siblings (patients 1 and 2 and 12 and 13) and the parents of patients 1 and 2 were first cousins.

\section{CLINICAL FINDINGS}

The age of presentation was between 1 month and 10 years (mean 2 years) (table 1 ). Table 1 gives the medical histories before diagnosis. Most patients had symptoms consistent with immunoglobulin deficiency, which included recurrent diarrhoea and vomiting, recurrent upper respiratory tract infections, otitis media, and failure to thrive. Seven children developed Pneumocystis carinii pneumonia; in six $P$ carinii pneumonia was the presenting feature in the first year of life and two of these children went on to have a second episode. In addition, there was one case of cytomegalovirus pneumonitis.

Additional features more consistent with cell mediated immunodeficiency were seen in most patients. Severe neurological disease occurred in five children, one (patient 14) had cryptococcal meningitis which responded to antifungal treatment. Two siblings had acute encephalitis. One (patient 1) recovered with high doses of intravenous immunoglobulin and intraventricular immunoglobulin, but the other (patient 2) died from encephalitis associated with the isolation of papovavirus from urine and adenovirus from stool samples. Two children (patients 9 and 13) died from idiopathic progressive neurological disorders. Three patients developed sclerosing cholangitis. Two died, one (patient 4) during liver transplantation, the second (patient 16) from hepatic failure. The disease is static in the third (patient 15). 
Table 1 Age, sex, ethnicity, family history, and medical histories in the hyper IgM syndrome

\begin{tabular}{|c|c|c|c|c|c|c|}
\hline $\begin{array}{l}\text { Patient } \\
\text { No }\end{array}$ & $\begin{array}{l}\text { Age at } \\
\text { diagnosis } \\
\text { (months) }\end{array}$ & $\operatorname{Sex}$ & $\begin{array}{l}\text { Ethnic } \\
\text { origin }\end{array}$ & $\begin{array}{l}\text { Family history and probable } \\
\text { inheritance pattern }\end{array}$ & Medical history before diagnosis & Status after diagnosis \\
\hline 1 & 40 & $\mathbf{M}$ & Indian & $\begin{array}{l}\text { Parents first cousins, brother of } \\
\text { patient } 2 \text {, autosomal recessive }\end{array}$ & $\begin{array}{l}\text { Cryptosporidiosis, combined adenovirus and } \\
\text { echovirus meningoencephalitis, recurrent } \\
\text { candidiasis, recurrent URTI }\end{array}$ & Well \\
\hline 2 & 72 & $\mathbf{F}$ & Indian & $\begin{array}{l}\text { Parents first cousins, sister of } \\
\text { patient } 1 \text {, autosomal recessive }\end{array}$ & $\begin{array}{l}\text { Recurrent URTI, encephalitis, aspergillus } \\
\text { pneumonia }\end{array}$ & Died from encephalitis \\
\hline 3 & 3 & $\mathbf{M}$ & English & Sporadic & $\begin{array}{l}\text { P carinii pneumonia, CMV pneumonitis, } \\
\text { recurrent URTI, recurrent diarrhoea and } \\
\text { vomiting }\end{array}$ & Well \\
\hline 4 & 9 & $\mathbf{M}$ & English & Sporadic & $P$ carinii pneumonia & $\begin{array}{l}\text { Cryptosporidiosis, cirrhosis secondary to scle- } \\
\text { rosing cholangitis, second attack of } P \text { carinii } \\
\text { pneumonia, died during liver transplanta- } \\
\text { tion }\end{array}$ \\
\hline 5 & 19 & $\mathbf{M}$ & English & Sporadic & $\begin{array}{l}\text { Recurrent chest infections, osteomyelitis, } \\
\text { recurrent cutaneous abscesses }\end{array}$ & $\begin{array}{l}\text { Recurrent chest infections, suspected tubercu- } \\
\text { lous osteomyelitis }\end{array}$ \\
\hline 6 & 10 & $\mathbf{M}$ & English & $\begin{array}{l}\text { Maternal uncle died at } 6 \\
\text { months, } \mathrm{X} \text { linked }\end{array}$ & Recurrent otitis media, red cell aplasia & $\begin{array}{l}\text { Neutropenia that responded to high doses of } \\
\text { intravenous immunoglobulin }\end{array}$ \\
\hline 7 & 7 & $\mathbf{M}$ & Pakistani & $\begin{array}{l}\text { Two brothers died at } 1 \text { year } \\
\text { (pneumonia) and } 2 \text { years } \\
\text { (gastroenteritis), immunology } \\
\text { uncertain, } X \text { linked }\end{array}$ & $\begin{array}{l}P \text { carinii pneumonia, recurrent URTI, can- } \\
\text { didiasis }\end{array}$ & $\begin{array}{l}\text { Ventilated for laryngotracheobronchitis, } \\
\text { associated soft tissue pseudomonas infection }\end{array}$ \\
\hline 8 & 6 & $\mathbf{M}$ & English & Sporadic & $P$ carinii pneumonia & $\begin{array}{l}\text { Pneumococcal pneumonia when not receiving } \\
\text { treatment }\end{array}$ \\
\hline 9 & 30 & $\mathbf{F}$ & Indian & Sporadic & Recurrent cutaneous abscesses & $\begin{array}{l}\text { Died from progressive idiopathic neurological } \\
\text { deterioration }\end{array}$ \\
\hline 10 & 6 & $\mathbf{M}$ & English & $\begin{array}{l}\text { Six male deaths over two gener- } \\
\text { ations: } \mathbf{X} \text { linked }\end{array}$ & $P$ carinii pneumonia & Well \\
\hline 11 & 120 & $\mathbf{M}$ & Iraqi & Sporadic & Recurrent URTI, recurrent otitis media & Well \\
\hline 12 & 48 & $\mathbf{M}$ & English & $\begin{array}{l}\text { Brother of patient } 13, \mathrm{X} \text { linked } \\
\text { or autosomal recessive }\end{array}$ & $\begin{array}{l}\text { Recurrent mouth ulcers, pericentric inver- } \\
\text { sion of chromosome } 7\end{array}$ & Well \\
\hline 13 & 5 & $\mathbf{M}$ & English & $\begin{array}{l}\text { Brother of patient } 12, \mathrm{X} \text { linked } \\
\text { or autosomal recessive }\end{array}$ & $\begin{array}{l}P \text { carinii pneumonia, giardiasis, developmen- } \\
\text { tal delay with pericentric inversion of chro- } \\
\text { mosome } 7\end{array}$ & $\begin{array}{l}\text { Recurrent } P \text { carinii pneumonia, progressive } \\
\text { idiopathic neurological deterioration, died } \\
\text { aged } 12 \text { years }\end{array}$ \\
\hline 14 & 30 & $\mathbf{M}$ & Greek & Sporadic & $\begin{array}{l}\text { Recurrent gastroenteritis, recurrent otitis } \\
\text { media and URTI, eczema }\end{array}$ & $\begin{array}{l}\text { Cryptococcal meningitis, erysipelas, neutrope- } \\
\text { nia responsive to granulocyte colony stimu- } \\
\text { lating factor and high dose intravenous } \\
\text { immunoglobulin }\end{array}$ \\
\hline 15 & 28 & $\mathbf{M}$ & Irish & Sporadic & $\begin{array}{l}\text { Recurrent bacterial infections, sclerosing } \\
\text { cholangitis }\end{array}$ & Well \\
\hline 16 & 17 & $\mathbf{M}$ & Greek & Sporadic & $\begin{array}{l}P \text { carinii pneumonia, recurrent chest infec- } \\
\text { tions and hepatosplenomegaly }\end{array}$ & Death from sclerosing cholangitis \\
\hline
\end{tabular}

URTI= upper respiratory tract infection: $\mathrm{CMV}=$ cytomegalovirus.

HAEMATOLOGY AND IMMUNOLOGY

Tables 2 and 3 give the haematological and immunological indices. IgG and IgA were low in all 16 patients, but were rarely undetectable. IgM was increased in seven patients and normal in nine. Six patients were neutropenic at presentation with neutrophil counts less than $1 \times 10^{9} /$. T lymphocyte enumeration showed a low $\mathrm{CD} 4$ count $\left(0.5 \times 10^{9} / 1\right.$, patient 11 ; table 3 ) in one patient and a low CD3 count $\left(1 \cdot 1 \times 10^{9} /\right.$, patient 12 , table 3$)$ in another. Phytohaemagglutinin stimulation was normal in all patients. No autoantibody was detected in the six patients screened.

\section{RESPONSE TO TREATMENT}

All patients received immunoglobulin replacement treatment, with a decrease in the frequency and severity of bacterial and viral infections. Opportunist infections, including cryptococcal, $P$ carinii pneumonia, and chronic cryptosporidial infections, have occurred, however, although with no relation with either intravenous immunoglobulin treatment or immunosuppression. Neutropenia resolved in all six patients once adequate doses of immunoglobulin treatment had been given. Granulocyte colony stimulating factor was used in combination with intravenous immunoglobulin in one patient. High doses of intravenous immunoglobulin were required to prevent infection (up to $1 \mathrm{~g} / \mathrm{kg}$, every three weeks). All but one child (who developed red cell aplasia while receiving co-trimoxazole) are being treated with prophylactic co-trimoxazole because of their susceptibility to $P$ carinii pneumonia.

\section{Discussion}

This report significantly increases the documented number of patients with this rare disorder and highlights the underlying $T$ cell immunodeficiency with the occurrence of opportunistic infections. Twelve of the 16 patients have not previously been described. The clinical descriptions of our patients add to the spectrum of diseases found in this disorder ${ }^{2}$ and emphasise the clinical evidence for a

Table 2 Haematological indices in children with hyper IgM syndrome

\begin{tabular}{|c|c|c|c|c|c|c|c|c|c|c|c|c|c|c|c|c|}
\hline & \multicolumn{16}{|c|}{ Patient No } \\
\hline & 1 & 2 & 3 & 4 & 5 & 6 & 7 & 8 & 9 & 10 & 11 & 12 & 13 & 14 & 15 & 16 \\
\hline $\begin{array}{l}\text { Haemoglobin }(\mathrm{g} / \mathrm{l}) \\
\text { Platelet count }\left(\times 10^{9} / 1\right) \\
\text { White cell count }\left(\times 10^{9} /\right) \\
\text { Lymphocyte count }\left(\times 10^{9} /\right) \\
\text { Neutrophil count }\left(\times 10^{9} / 1\right) \\
\text { Monocyte count }\left(\times 10^{9} /\right)\end{array}$ & $\begin{array}{r}105 \\
274 \\
6 \cdot 9 \\
4 \cdot 2 \\
2 \cdot 4 \\
0 \cdot 2\end{array}$ & $\begin{array}{r}94 \\
300 \\
5 \cdot 0 \\
1 \cdot 4 \\
3 \cdot 4 \\
0 \cdot 1\end{array}$ & $\begin{aligned} 105 \\
726 \\
17 \cdot 8 \\
9 \cdot 4 \\
7 \cdot 7 \\
0 \cdot 5\end{aligned}$ & $\begin{aligned} 134 \\
\text { N/A } \\
18 \cdot 6 \\
12 \cdot 9 \\
6 \cdot 1 \\
0 \cdot 2\end{aligned}$ & $\begin{array}{r}133 \\
500 \\
5 \cdot 1 \\
3 \cdot 5 \\
0 \cdot 7 \\
0.9\end{array}$ & $\begin{array}{r}47 \\
435 \\
12 \cdot 6 \\
9 \cdot 6 \\
0.3 \\
0.9\end{array}$ & $\begin{array}{l}100 \\
\text { N/A } \\
10 \cdot 2 \\
9 \cdot 5 \\
0 \cdot 2 \\
0 \cdot 2\end{array}$ & $\begin{array}{r}120 \\
830 \\
33 \cdot 5 \\
15 \cdot 1 \\
18 \cdot 4 \\
0 \cdot 0\end{array}$ & $\begin{array}{r}97 \\
697 \\
11 \cdot 8 \\
1 \cdot 8 \\
9 \cdot 7 \\
0 \cdot 2\end{array}$ & $\begin{array}{l}120 \\
\text { N/A } \\
18 \cdot 3 \\
7 \cdot 1 \\
7 \cdot 5 \\
0 \cdot 0\end{array}$ & $\begin{array}{r}119 \\
315 \\
17 \cdot 4 \\
5 \cdot 7 \\
10 \cdot 6 \\
1 \cdot 0\end{array}$ & $\begin{array}{r}106 \\
268 \\
3 \cdot 5 \\
2 \cdot 5 \\
0 \cdot 4 \\
0 \cdot 5\end{array}$ & $\begin{array}{r}124 \\
335 \\
16 \cdot 8 \\
12 \cdot 0 \\
2 \cdot 5 \\
0 \cdot 7\end{array}$ & $\begin{array}{l}\text { N/A } \\
200 \\
8 \cdot 6 \\
4 \cdot 8 \\
3 \cdot 8 \\
0 \cdot 0\end{array}$ & $\begin{array}{r}109 \\
132 \\
2 \cdot 1 \\
1 \cdot 9 \\
0 \cdot 1 \\
0 \cdot 0\end{array}$ & $\begin{array}{r}103 \\
\text { N/A } \\
2 \cdot 0 \\
1 \cdot 6 \\
0 \cdot 2 \\
0 \cdot 2\end{array}$ \\
\hline
\end{tabular}

$\mathrm{N} / \mathrm{A}=$ not available. 
Table 3 Immunological indices in children with hyper IgM syndrome (reference ranges in brackets)

\begin{tabular}{|c|c|c|c|c|c|c|c|c|c|c|c|c|c|c|c|c|}
\hline & \multicolumn{16}{|l|}{ Patient No } \\
\hline & 1 & 2 & 3 & 4 & 5 & 6 & 7 & 8 & 9 & 10 & 11 & 12 & 13 & 14 & 15 & 16 \\
\hline $\operatorname{IgG}(g /)$ & $\begin{array}{l}1 \cdot 7 \\
(4 \cdot 7-14 \cdot 8)\end{array}$ & $\begin{array}{l}3 \cdot 6 \\
(5 \cdot 5-14 \cdot 0)\end{array}$ & $\begin{array}{l}1 \cdot 1 \\
(3 \cdot 0-13 \cdot 0)\end{array}$ & $\begin{array}{l}0 \cdot 2 \\
(2 \cdot 6-9 \cdot 6)\end{array}$ & $\begin{array}{l}1 \cdot 0 \\
(4 \cdot 2-12 \cdot 0)\end{array}$ & $\begin{array}{c}0 \cdot 8 \\
(2 \cdot 6-9 \cdot 6)\end{array}$ & $\begin{array}{l}0.5 \\
(3 \cdot 0-9 \cdot 0)\end{array}$ & $\begin{array}{l}0 \cdot 1 \\
(2 \cdot 0-11 \cdot 2)\end{array}$ & $\begin{array}{c}1 \cdot 7 \\
(4 \cdot 2-12 \cdot 0)\end{array}$ & $\begin{array}{l}<0 \cdot 6 \\
(2 \cdot 6-9 \cdot 6)\end{array}$ & $\begin{array}{l}<0 \cdot 9 \\
(6 \cdot 0-16 \cdot 0)\end{array}$ & $\begin{array}{l}.0 \cdot 5 \\
(5 \cdot 5-14 \cdot 0)\end{array}$ & $\begin{array}{l}0 \cdot 7 \\
(2 \cdot 6-9 \cdot 6)\end{array}$ & $\begin{array}{l}2 \cdot 5 \\
(6 \cdot 0-11 \cdot 0)\end{array}$ & $\begin{array}{l}3 \cdot 8 \\
(4 \cdot 2-12 \cdot 0)\end{array}$ & $\begin{array}{l}<0.6 \\
(5 \cdot 0-10 \cdot 0)\end{array}$ \\
\hline $\operatorname{Ig} A(g /)$ & $\begin{array}{l}0.2 \\
(0.4-1 \cdot 9)\end{array}$ & $\begin{array}{l}0.03 \\
(0.4-1.9)\end{array}$ & $\begin{array}{l}0.1 \\
(0 \cdot 4-1.5)\end{array}$ & $\begin{array}{l}0.03 \\
(0 \cdot 2-1 \cdot 0)\end{array}$ & $\begin{array}{l}0.09 \\
(0 \cdot 2-1 \cdot 3)\end{array}$ & $\begin{array}{l}<0.02 \\
(0 \cdot 2-1 \cdot 0)\end{array}$ & $\begin{array}{l}0 \cdot 2 \\
(0 \cdot 2-1 \cdot 1)\end{array}$ & $\begin{array}{l}0.08 \\
(0.1-0.9)\end{array}$ & $\begin{array}{l}<0 \cdot 1 \\
(0 \cdot 24-1 \cdot 3)\end{array}$ & $\begin{array}{c}0.03 \\
(0 \cdot 2-1 \cdot 0)\end{array}$ & $\begin{array}{l}<0 \cdot 20 \\
(0 \cdot 6-2 \cdot 8)\end{array}$ & $\begin{array}{l}0 \cdot 4 \\
(0 \cdot 4-1 \cdot 9)\end{array}$ & $\begin{array}{l}0.05 \\
(0 \cdot 2-1 \cdot 0)\end{array}$ & $\begin{array}{l}0 \cdot 2 \\
(0 \cdot 4-1 \cdot 2)\end{array}$ & $\begin{array}{l}0 \cdot 03 \\
(0 \cdot 24-1 \cdot 3)\end{array}$ & $\begin{array}{l}<0.02 \\
(0.4-1 \cdot 2)\end{array}$ \\
\hline $\operatorname{IgM}(\mathrm{g} / \mathrm{I})$ & $\begin{array}{l}0 \cdot 7 \\
(0 \cdot 3-1 \cdot 5)\end{array}$ & $\begin{array}{l}0.6 \\
(0.4-1.9)\end{array}$ & $\begin{array}{l}1.59 \\
(0 \cdot 4-2 \cdot 0)\end{array}$ & $\begin{array}{l}3 \cdot 3 \\
(0 \cdot 3-1 \cdot 5)\end{array}$ & $\begin{array}{l}4 \cdot 9 \\
(0 \cdot 4-1 \cdot 8)\end{array}$ & $\begin{array}{c}0.5 \\
(0 \cdot 3-1 \cdot 5)\end{array}$ & $\begin{array}{l}1 \cdot 3 \\
(0 \cdot 4-1 \cdot 6)\end{array}$ & $\begin{array}{l}1 \cdot 0 \\
(0 \cdot 1-0 \cdot 8)\end{array}$ & $\begin{array}{c}1.3 \\
(0 \cdot 4-1 \cdot 8)\end{array}$ & $\begin{array}{c}0.4 \\
(0.3-1 \cdot 5)\end{array}$ & $\begin{array}{l}31 \cdot 0 \\
(0 \cdot 5-2 \cdot 1)\end{array}$ & $\begin{array}{l}1.5 \\
(0 \cdot 4-1 \cdot 8)\end{array}$ & $\begin{array}{l}0.8 \\
(0 \cdot 3-1 \cdot 5)\end{array}$ & $\begin{array}{l}4 \cdot 8 \\
(0 \cdot 8-1 \cdot 6)\end{array}$ & $\begin{array}{l}8 \cdot 26 \\
(0 \cdot 4-1 \cdot 8)\end{array}$ & $\begin{array}{c}8 \cdot 0 \\
(0 \cdot 6-1 \cdot 4)\end{array}$ \\
\hline $\begin{array}{c}\mathrm{CD} \text { count } \\
\left(\times 10^{\circ} /\right)\end{array}$ & Normal & Normal & Normal & Normal & Normal & Normal & Normal & Normal & Normal & Normal & $\begin{array}{c}\text { CD4 low } \\
(0.5)\end{array}$ & $\begin{array}{c}\text { CD3 low } \\
(1 \cdot 1)\end{array}$ & Normal & Normal & Normal & Normal \\
\hline
\end{tabular}

T lymphocyte deficiency which may underlie the hypogammaglobulinaemia. The molecular basis of the $\mathrm{X}$ linked form of hyper IgM has been shown to be due to abnormalities of a T lymphocyte activation molecule. 56

Most patients presented with respiratory symptoms in the first year of life and later had bacterial and viral infections which were well controlled with intravenous immunoglobulin. Relatively high doses of intravenous immunoglobulin were often required to control symptoms, particularly the neutropenia commonly associated with the syndrome. The mechanism for an improvement in the neutrophil count may have been the modulation of an autoimmune process, but may also have been the result of preventing infections causing secondary neutropenia. This emphasises the importance of considering secondary phenomena when describing the immunophenotype of an immunodeficiency disorder, particularly those due to single gene defects. This is well illustrated in this disorder where the high concentrations of $\operatorname{IgM}$ can be shown to be secondary by the return of the IgM to normal or subnormal levels once infection has been controlled and prevented.

Infections such as $P$ carinii, Cryptococcus neoformans, cryptosporidia, cytomegalovirus, and other viruses which are more characteristic of T lymphocyte deficiency were more prominent in this series than in previous reviews. ${ }^{29}$ As in other series, however, the outstanding laboratory abnormality in these patients was very low concentrations of IgG and IgA with apparently normal $\mathrm{T}$ cell function. In contrast with the other more common form of $\mathrm{X}$ linked hypogammaglobulinaemia, there were normal or increased numbers of circulating B lymphocytes capable of producing normal or increased amounts of IgM but not IgG or IgA. This implies disturbance of the normal mechanism whereby B lymphocytes producing IgM mature to produce cells able to produce other immunoglobulin isotypes. ${ }^{10}$ This mechanism has been shown to be intrinsically intact in B lymphocytes from affected subjects, ${ }^{1011}$ and is controlled by $T$ lymphocytes. Thus, both the clinical spectrum and laboratory findings suggest that $\mathrm{X}$ linked hyper IgM syndrome is a primary $T$ lymphocyte abnormality. This would explain the failure to detect nonrandom $\mathrm{X}$ chromosome inactivation in the B lymphocytes of obligate carriers. ${ }^{11} 12$

In addition to the overall high frequency of opportunistic infections, certain other clinically important findings deserve emphasis.
Features not previously described in association with this syndrome include sclerosing cholangitis (two deaths) and severe neurological disease, which was fatal in three patients.

The aetiology of hepatic and neurological disease may have been due to infection or an autoimmune process. The clinical feature which particularly emphasises the $\mathrm{T}$ lymphocyte deficiency in this disorder is $P$ carinii pneumonia. $P$ carinii pneumonia was a prominent finding with seven of 16 patients affected, six of whom had $P$ carinii pneumonia on presentation. This point is particularly important in the differential diagnosis of infants presenting with interstitial pneumonia, most of whom are assumed to have congenital HIV infection or, less commonly considered, severe combined immunodeficiency. In two patients $P$ carinii pneumonia recurred while receiving immunoglobulin replacement treatment, and all patients should receive long term $P$ carinii pneumonia prophylaxis. Only seven other cases of hyper IgM have had documented $P$ carinii pneumonia, ${ }^{2}$ all occurring in boys, suggesting that this is a feature of the $\mathrm{X}$ linked form of the disorder.

1 Rosen FS, Kevy SV, Merler E, Janeway CA, Gitlin D. globulinemia: deficiency of $7 \mathrm{~S}$ gamma-globulins in the 1961; 28: 182-95.

2 Notarangelo LD, Duse M, Ugazio AG. Immunodeficiency with hyper-IgM (HIM). Immunodeficiency Reviews 1992; 3: 101-21.

3 Padayachee M, Levinsky RJ, Kinnon C, et al. Mapping of the $\mathrm{X}$-linked form of hyper IgM syndrome (HIGMI) to Xq26 by close linkage to HPRT. Genomics 1992; 14: 551-3.

4 Brahmi Z, Lazarus KH, Hodes ME, Baehner RL. Immunologic studies of three family members with the immunodeficiency with hyper-IgM syndrome. f Clin immunodeficiency with hyp

5 Korthäuer U, Graf D, Mages HW, et al. Defective expression of T-cell CD40 ligand causes X-linked immunodeficiency with hyper-IgM. Nature 1993; 361: 539-41.

6 Allen RC, Armitage RJ, Conley ME, et al. CD40 ligand gene defects responsible for X-linked hyper-IgM syndrome. Science 1993; 259: 990-3.

7 Lau YL, Levinsky RJ, Morgan G, Strobel S. Dual meningoencephalitis with echovirus type II and adenovirus in combined (common variable) immunodeficiency. Pediatr Infect Dis $\mathcal{F}$ 1988; 7: 873-6.

8 Marshall WC, Weston HJ, Bodian M. Pneumocystic carini pneumonia and congenital hypogammaglobulinaemia.

9 Stiehm ER, Chin TW, Haas A, Peerless AG. Infectious complications of the primary immunodeficiencies. Clin Immunol Immunopathol 1986; 40: 69-86.

10 Mayer L, Kwan SP, Thompson C, et al. Evidence for a defect in 'switch' $T$ cells in patients with immunodeficiency and hyperimmunoglobulinemia. $N$ Engl $f \mathrm{Med}$ 1986; 314: 409-18.

11 Hendriks RW, Kraakman MEM, Craaig IW, Espanol T, Schuurman RKB. Evidence that in X-linked immunodeficiency with hyperimmunoglobulinemia $M$ the intrinsic immunoglobulin heavy chain class switch mechanism is intact. Eur f Immunol 1990; 20: 2603-8.

12 Goodship J, Callard R, Malcolm S, Levinksy RJ Investigation of $\mathrm{X}$ chromosome use in an obligate carrie of hyper IgM syndrome. In: Chapel HM, Levinsky RJ Webster ADB, eds. Progress in immune deficiency III. London: Royal Society of Medicine, 1990: 273. 